\title{
Energy Consumption in Indian Non-Ferrous Industries: Need for Bench Marking of Data
}

\author{
M. Ghosh ${ }^{1, *}$, D. De Sarkar ${ }^{2}$, P. S. Bane rjee ${ }^{1}$, H. S. Ray ${ }^{1}$ \\ ${ }^{1}$ Department of Metallurgy and Materials Engineering, Bengal Engineering and Science University, Shibpur, Howrah, 711 103, India \\ ${ }^{2}$ Indian Copper Development Centre, Kolkata, 700 016, India
}

\begin{abstract}
Being an energy-intensive industry, the energy usage pattern in the non-ferrous metal industry merits close observation with the intention to bring down specific energy consumption for all metals. United Nations Industrial Development Organization (UNIDO) has taken up extensive programmes for international benchmarking, based on data available from individual industries of various countries. Major producers of non-ferrous metals across the globe have initiated measures to reduce energy consumption per unit weight of product at important production steps and have gained substantial benefits. Adoption of superior technology has been shown to also mitigate emission of toxic gases. Extensive Reports and Reviews, particularly from the European Union countries and organizations such as International Aluminium Institute, have made available extensive verifiable data on the energy usage by the member countries. However, although the non-ferrous metal sector in India has been on expansion mode, the industry in general is reluctant to publish data on energy usage in various plants and measures to mitigate emissions. The actions of concerned government agencies in this direction are neither transparent nor available in public do main. Extensive and verifiable data for each step of production can identify Best Practice Technology (BPT) as a first step, based on which subsequently benchmarking standards for energy consumption can be arrived at.
\end{abstract}

Keywords Non-ferrous Industry, Energy Bench marking, Best Practice Technology

\section{Introduction}

There has been growing global concern on the rise in energy consumption in industrial sectors in particular, and the resulting adverse impact on environment. With current industrial growth average temperature of earth's surface is expected to rise by $2^{\circ} \mathrm{C}$ by 2030 and the associated undesirable effects are unavoidable. This concern is reflected in a number of Energy Surveys based on statistical data collected from various industrial sectors conducted by individual countries. Special mention must be made on the survey conducted by United Nations Industrial Development Organization (UNIDO)[1] on global industrial Energy Efficiency in a number of specific manufacturing sectors, published in 2010. According to this Report, an energy usage of 127 Exo-joules $\left(E J=10^{18} \mathrm{~J}\right)$ in 2007 can be used as a starting point to project the energy demand in the coming decades. Reports indicate that it possible to save about $24 \mathrm{EJ}$ in a year, provided adequate and in-depth information on energy usage in each sector is considered. Various surveys admit that adequate data is not

* Corresponding author:

manojit_ghosh1@rediffmail.com(M. Ghosh)

Published online at http://journal.sapub.org/ijmee

Copyright (C) 2012 Scientific \& Academic Publishing. All Rights Reserved available for specific industrial manufacturing sectors in many countries, including Indian non-ferrous metal extraction industries. Identifying the Best Practice Technology (BPT) at the beginning and its wide application can bring immediate benefits for each industry. Lack of adequate data base is a major obstacle for analys is of energy usage in a given industry and comparison between plants manufacturing similar products.

The specific energy consumption (Gcal per ton of crude steel) for leading steel making companies in India can be found in reports and literatures[2]. These figures clearly provide a clear picture about the trends in energy consumption and other related is sues. Unfortunately similar data is not available for Indian industries producing $\mathrm{Al}, \mathrm{Cu}$, $\mathrm{Zn}, \mathrm{Pb}$ etc. although a major portion of energy is consumed through them.

\section{Critical Importance of Need for Energy Reduction}

Extraction of Non-ferrous metals to obtain marketable products, because of the very nature of the mineral resources and thermodynamic stability of the co mpounds of the metals, involve energy intensive processes. On top of that, these industries are the sources of tremendous amount of direct pollution due to noxious gases due to the fact that many 
non-ferrous metals such as copper, lead, zinc and nickel are obtained from sulphide minerals; and indirect pollution in terms of $\mathrm{CO}$ or $\mathrm{CO}_{2}$ emitted. In addition, since unlike iron, the non-ferrous metals, except alu min ium, are obtained from relatively lean ores, tremendous amount of energy consumption is involved in the mineral dressing circuit. Relatively less attention has been paid towards analyzing energy consumption pattern in individual steps such as in comminution and concentration circuits to produce concentrates from ores of non-ferrous metals. The EU sponsored Sector Report[3] on Non-ferrous metals industry, which gives break-up of $\mathrm{GHG}$ and $\mathrm{CO}_{2}$ emission, starts the analysis from processing of concentrates. Emissions and energy usage pattern in mineral dressing to produce the concentrate, has not yet been taken into account.

Canadian Industrial Energy End-use Data and Analysis Centre (CIEEDAC)[4] has been performing remarkable task of collecting, collating and analyzing detailed industrial production data, including the usually neglected area of mining. According to CIEEDAC Report of 2011, comparison of data between 1990 to 2009 on energy usage and GHG emission shows that energy consumption had decreased by $10.6 \%$ with corresponding reduction of GHG emission by $9.5 \%$ by proper energy survey and subsequent adaptation of the recommended measures. Such detailed data analysis, as reported by European paves the way for comparing energy usage data for plants with similar technology so as to identify the Best Practice Technology (BPT), which in turn, can be the basis of Benchmarking

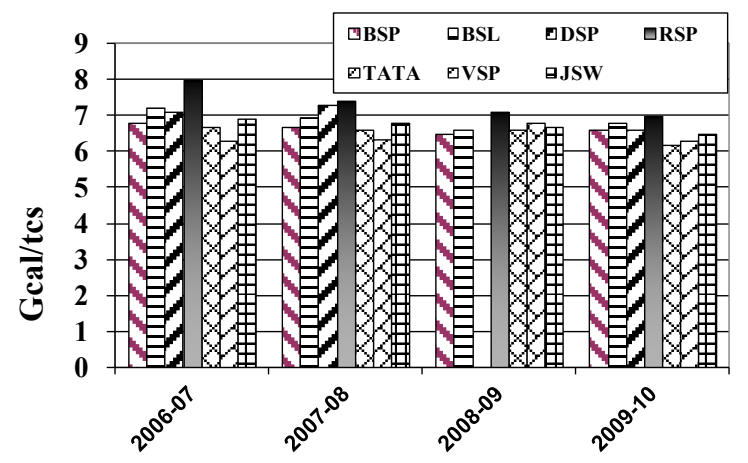

(a)

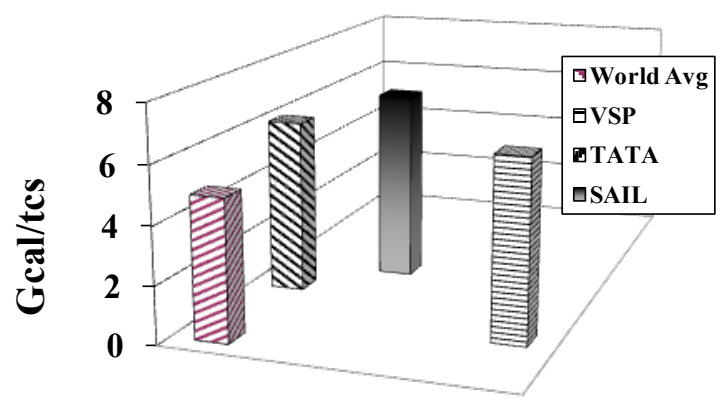

(b)

Figure 1. Specific energy consumption trends in Indian Steel industries (b) Comparison of specific energy consumption levels of an image with acceptable resolution

\section{Technology Upgradation, GHG Emission and Non-ferrous Metal Industries}

Another fall out of increasing production of non-ferrous metals sector is the soaring carbon foot print. The Bureau of International Recycling (BIR), in its report in 2008[5,6] estimates a 'carbon footprint' of more than 1100 kilo tons of $\mathrm{CO}_{2}$ for non-ferrous metals sector. Similar data. presented elsewhere[3] show a larger scatter, which is expected because of difference in metal values in the concentrates, the fuel used, especially the usage of electricity, the technology used etc. It is interesting to note that the Imperial Smelting process (ISP), although an efficient process of treating lead-zinc sulphide concentrates after agglomeration, involves a high degree of $\mathrm{CO}_{2}$ emis sion because the smelting process involves carbothermic reduction. Table 1 shows specific direct $\mathrm{CO}_{2}$ emissions for various non-ferrous metals at different levels of their production.

Table 1. Emission of $\mathrm{CO}_{2}$ in Primary Extraction of a Few Non-ferrous Metals[6]

\begin{tabular}{|c|c|}
\hline Activity & SDCE $^{\#}$ \\
\hline Copper - Primary smelting to produce cathode & 1140 \\
\hline Copper - secondary smelt ing from scrap & 310 \\
\hline $\begin{array}{c}\text { Zinc- Roast-leach-electrowin (RLE) route with } \\
\text { hydromet.treatment of leach residue }\end{array}$ & 43 \\
\hline $\begin{array}{c}\text { Zinc - RLE with pyromet. Treatment of leach } \\
\text { residue }\end{array}$ & 1425 \\
\hline Zinc- Imperial Smelting process & 4325 \\
\hline Lead- primary production & 1459 \\
\hline Nickel - primary production & 1340 \\
\hline Aluminium - i) Direct CO ${ }_{2}$ from Hall cell & 1600 \\
ii) PFC (poly-fluorocarbons) & $3380 \mathrm{CO}_{2}$ \\
iii) Pre-bake anode & 270 \\
\hline
\end{tabular}

\# Specific direct $\mathrm{CO}_{2}$ emission, $\mathrm{Kg} / \mathrm{CO}_{2}$ per tonne of product

All the above values in the context of energy intensity and emission of polluting and GHG are dependent on the technology used and the resource of raw materials available. As a result, when the producers of non-ferrous metals adopt measures to improve productivity, specific energy consumption and specific emission of GHG show a downward trend. A case in point is the emission of Poly-fluorocarbons (PFC), such as $\mathrm{CF}_{4}$ and $\mathrm{C}_{2} \mathrm{~F}_{6}$ during production of aluminium, which has been a major cause of concern. The adverse effect of PFCs on Global Warming Potential (GWP) is tremendous. One $\mathrm{kg}$ of $\mathrm{CF}_{4}$ has GWP of $6500 \mathrm{~kg}$ of $\mathrm{CO}_{2}$ and one $\mathrm{kg}$ of $\mathrm{C}_{2} \mathrm{~F}_{6}$, has GWP of 9200[7]. Emissions of PFC occur particularly when Anode Effect takes place due to reduced concentration of dissolved alumina in cryolite. These emissions can be significantly reduced by adopting measures to minimize anode effects, by using proper sensors, better alumina charging procedures and more use of co mputer-control of the cells. Data over the last two decades confirms this fact. In 1998, total PFC emission in aluminium s melting was 98 million tonne (Mt) $\mathrm{CO}_{2}$ equivalent. This figure has been progressively lowered 
to $58 \mathrm{Mt}$ in 2000 and $39 \mathrm{Mt}$ in $2010[8]$. Thus, even in the gloomy scenario of inevitable escalating GHG emission fro $m$ industry, some mitigation steps have been proved to be fruitful. It must be mentioned that under the aegis of the concerned governments in USA and Europe, in China and Chile, there has been extensive and effective involvement of academic institutions, R \& D organizations and the industry in the common efforts towards reducing energy usage.

\section{The Scenario in India}

\subsection{The Pros pect of Non-ferrous Industry}

There has been a spurt in the non-ferrous metal industry in India after the sector was thrown open for private enterprises. The increase in production of the four primary non-ferrous metals is shown in the following Table 2:

Table 2. Production of Primary Non-ferrous Metals in India in Tons[9]

\begin{tabular}{|c|c|c|c|}
\hline Metal & $\sim 1980$ & 2009 & 2011 \\
\hline Aluminium & 250,000 & 650,000 & 1630,000 \\
\hline Copper & 50,000 & 650,000 & 664,000 \\
\hline Zinc & 100,000 & 585,000 & 712,000 \\
\hline Lead & 35,000 & 61,000 & 71,000 \\
\hline
\end{tabular}

Among the non-ferrous metals produced in India, the prospect of alu minium is particu larly bright. While gibbsitic aluminium ore resources in the world are depleting, vast deposits of gibbsite in India assume particular interest because of its ease of processing. Since gibbsite processing has specific advantage of low energy consumption in digestion, the alumina refineries enjoy sustainable comparative cost advantage. Per capita consumption of aluminium in India is only about $0.8 \mathrm{~kg}[10]$. The Planning Commission of India has projected production of aluminium at 1.28 million tonnes by 2012 (@8\% growth rate) and 1.5 million tonnes by 2017. The demand for corresponding years is projected at 1.35 million tonnes and 1.5 million tonnes, respectively[10]. With the advent of private enterprises in the open market in India, there has been a shift in. production pattern - from exclusive primary producers, including public sector undertakings which owned mines in India, to energetic private players who import concentrates in the large scale for smelting and refining in India. If power situation becomes more conducive, the primary metal production in India would have a healthy export market. One constraint for growth of other non-ferrous metal industry is that except bauxite, India does not have high grade of ores for other non-ferrous metals.

By 2020, India would have an aluminium capacity of 17-20 lakh tpa. For a country endowed with nearly 10 per cent (2,525 million tonnes) of the world's bauxite reserves and having the lowest cost of production, this capacity would be technically justified. Thus, India's vision for 2020, besides being a global player in terms of size, should also include achieving international standards in terms of consumption. Today, 35 per cent of Indian aluminium is consumed by the power industry, compared with less than 10 per cent in USA and Japan. Areas like construction and packaging where global alu miniu m consumption thrives, has low relevance to India. Barely 6 per cent of the aluminium finds its way in the construction industry compared with 17 per cent in USA and 25 per cent in Japan. The Indian construction industry, which is headed for promising growth, can, therefore, be a major demand driver.

Copper industry has three players producing primary refined copper viz. Hindusthan Copper Limited (HCL), Sterlite Industries (Vedanta Group) and Birla Copper (Hindalco Grour). HCL is the only integrated primary producer having own indigenous mining activity. Birla Copper and Sterlite Industries are Custom Smelters and operate with imported concentrate. All these units produce refined copper cathode and copper CCR rod. Since the domestic production of copper cathode has increased substantially, import of copper cathode has reduced drastically. In fact, India now exports both copper cathode and copper CCR rod.

By 2020, refined copper production capacity in India is projected to rise to 16-18 lakh tpa, going by the growth in domestic demand. From 4 lakh tonnes in 2003, copper demand has been estimated to grow at average $8 \%$ annually, much higher than world demand growth (3\%). Because India has to rely on imported copper concentrates to feed its smelters, international prices would hold the key not only to future expansion projects but also sustenance of existing capacity. In the coming years, a major shift is expected in the sourcing pattern, from conventional imports to acquisition of mining rights abroad. Viewing this, the AV Birla group has acquired mining rights in two copper mines in Australia. In 2008, Sterlite Industries Limited purchased the United States' third largest copper producer, Asarco. This trend would need to persist if domestic capacity utilisation and further capacity expansion are to be ensured. In addition to growing domestic market, export would be a thrust area for Indian Copper Industry. This is applicable for both primary copper producers and down stream semis manufacturers.

After steel, aluminum and copper, zinc is the fourth most widely used metal globally. The Indian Zinc industry is now completely under the private sector and is in the midst of major expansion programme. There is an indication that zinc demand grew by $10 \%$ till 2010 and $7 \%$ thereafter. In the year 2020 India would require zinc capacity of 14 lakh tpa, in order to be self-reliant. As India was one of the first countries to gain the knowledge of extracting zinc from zinc ores and start the production of zinc metal, it should have been a top player in the world zinc market but this has not been the case. However, the scenario is changing fast and in 2010 India became $3^{\text {rd }}$ largest producer of zinc. Indian zinc industry consists of two large players, namely Hindustan Zinc and BinaniZinc. While, Hindustan Zinc is an integrated producer which is having its own mines, Binani Zinc is a custom smelting producer. All the major zinc ore mines in India viz. Rampura Agucha, Rajpura Dariba and Zawar mines are located in the state of Rajasthan and all of these are under the control of Hindustan Zinc. In India, zinc consumption has 
increased from 347,000 tonnes in 2004 to 516000 tonnes in 2010 , backed by demand from infrastructure and other end use sectors. The metal is important for galvanizing accounted for around $70 \%$ of the total consumption.

\section{Steps Taken by the Industry to Reduce Energy Usages}

\subsection{Alumi nium}

Energy and alumina costs represent the largest components for the global alu miniu m industry. Energy costs represent around 30 per cent of the total smelting cost of alu min iu m and around one-third of total a lu mina production costs. Table 3 shows the cost of energy required for aluminium production in India. During 2002-06, energy costs have increased drastically due to increase in crude oil prices. In India, the energy cost represents 40 per cent of manufacturing cost for aluminium and 30 per cent for fin ished rolled products.

Table 3. The Cost of Energy (in Percentage) During Aluminum Production in India

\begin{tabular}{|c|c|}
\hline Cost & \% energy used \\
\hline Alumina Production & 41 \\
\hline Smelting & 28 \\
\hline Processing Raw Materials & 12 \\
\hline Other & 19 \\
\hline
\end{tabular}

Vedanta Group, the largest company with high stakes in non-ferrous metal production having aluminium, copper, zinc and lead plants in many locations in India, reports[11] specific energy use for aluminium s melt ing in Hall cell, from the lowest figure of $14950 \mathrm{kwh} /$ tonne of a lu miniu m from a modern plant, which is also the figure for NALCO- another modern plant to $17676 \mathrm{kwh} /$ tonne from MALCO, an older plant with smaller cells of lower capacity. However, the international benchmark is $13000 \mathrm{kwh} /$ tonne of aluminium and effort are going on to bring down the value even further. BALCO, a part of Vedanta group, reports [11,12] a decrease in energy intensity in aluminium production from 60.52 to $57.25 \mathrm{GJ} / \mathrm{t}$ a lu min ium. Vedanta group is set to reduce power consumption by adopting a number of measures such as changing over fro $m$ Soderberg electrode to the more efficient pre-baked anode system in their expansion programme, which emits less PFC since Anode Effect is mitigated [International alu miniu m Institute, 201 1]. In addition, R \& D collaboration has been mooted for recovery of values from red mud and possible use of red mud for cement making.

\subsection{Copper}

Sterlite a major producer of copper, in its 'Sustainability Report' of 2010-2011[14] anticipated energy reduction steps, but details are not available.

\subsection{Zinc}

Zinc production unit of HZL Vedanta Resources at Vizag reported specific energy consumption of $4400 \mathrm{kwh}$ per tonne of zinc in 2006, which is lower than the figure of the year 2003-04 which was $4471 \mathrm{kwh}$ per tonne of zinc. HZL had reduced energy consumption by (a) imp rovements in design in the cell house, adopting steps to reduce impurity content of leach liquor, straightening the anode, using spacers between anodes (b) better control of leaching circuit (c) making the motors, pumps and co mpressed air system more efficient by using better equipment, plugging leakages etc.

An important initiative on Energy survey had been undertaken by Indira Gandhi Institute of Development Research, Mumbai[10], focusing on specific metal industry sector. It is noted that the steel industry in India, in general, has displayed awareness for energy assessment in different units in the line of the international practice. However, such a survey is required for the non-ferrous metal sector for which organized energy analys is is not adequate. It is hoped that the concerned Ministry of the Govern ment of India, through the Bureau of Energy Efficiency (BEE) would obtain detailed and authentic data from each plant for the purpose of comparison so that Best Practice Technology (BPT) can be identified as a first step.

\section{Conclusions}

The importance of energy survey as a basis of preparing a data base for determination of parameters of benchmarking cannot be over-emphasized. Reduction of overall energy consumption as well as "energy intensity" (the energy consumption per unit of output) is critical for India.

In view of the prospect of upward swing in production of metals in India in the near future, emission of gases which pose health hazard to the public would also increase inevitably. In view of this, there should be complete transparency in the data base for energy usage, gaseous emissions, and solid and liquid wastes.

The Govern ment should ensure the active involvement of academic institutions and similar bodies in the national drive for energy consumption which has been proved to be effective in other countries, even though there may be initial reluctance of the industries

\section{REFERENCES}

[1] UNIDO Working Paper on "Global Industrial Energy Efficiency Benchmarking An Energy Policy Tool”, November 2010

[2] Roy B., "High Growth Trajectory for Indian Steel Industry: Some thought towards Improving Its Sustainability", Green Earth, 2 (2), 35-39, 2011.

[3] Sector Report on "Non-ferrous metals industry for the European Commission' - Methodology for the free allocation of emission allowances in the -EU ETS post 2012", November 2009.

[4] Nyboer J. and Rudd S., "A Review of Energy Consumption and Related Data: Canadian Mining and Metal Smelting and 
Refining Industries 1990 to 2009" Canadian Industrial Energy End-use Data and Analysis Centre (CIEEDAC), 2011.

[5] Grimes S., Donaldson J., and Gomez G.C.,"Report on the Environmental Benefits of Recycling", Bureau of International Recy cling - Centre for Sustainable Production \& Resource Efficien cy, Imperial College London, 2008.

[6] Online available: IAI: <www.world-alumina.org> of International Aluminium Institute and IPCC 1995

[7] Bernstein L., Roy J., Metz B., Davidson O.R., Bosch P.R., Dave R., Meyer L.A., "Mitigation. Contribution of Working Group III to the Fourth Assessment Report of the Inter-governmental Panel on Climate Change", Climate Change, Cambridge University Press, Cambridge, United Kingdom and New York, NY, USA, 2007.

[8] Indian plant data

[9] Govt. of India Report No. 12, <Aluminium and Alumina>, Ministry of Mines.
[10] Ray B. K. and Reddy B.S., "Decomposition of Energy Consumption and Energy Intensity in Indian Manufacturing Industries", Indira Gandhi Institute of Development Research, Mumbai; WP- 2007-020, 2007.

[11] Report no. 2009-1055, Vedanta group: validation report; Det Norske Veritas.

[12] "India Brand equity Foundation-Metals, Market and opportunities", Metal World, Project Monitor Economic Research India Limited, 36-41, 2008.

[13] "Results of 2010 Anode Effect Survey", Report on the Aluminium Industry's Global Perfluorocarbon Gases Emissions Reduction Programme, Published by International aluminium Institute, London, 25-31, 2011.

[14] Sustainability Report; Sterlite, Online available: http://www. sterliteindustries.com/microsite.html, 2010-2011 